\title{
The Present Situation and Characteristics of Related Party Transactions in Listed Companies
}

\author{
M. Eovindaraju \\ Institut STIAMI
}

\begin{abstract}
This study aims to review related transactions that are affected by affiliated parties. Affiliated parties are an ownership relationship between one company and another company caused by the relationship between one party and the other that is not found in a normal relationship. The term tax-related relationship is usually used in tax cases relating to affiliated transactions or transactions of related parties. Transfer Pricing in related transactions is defined as a special selling price used in inter-divisional exchanges to record the selling division's revenue and the buying division's costs. The main purpose of transfer pricing is to evaluate and measure the performance of a company. However, in many practice findings, transfer pricing is used by companies to minimize the number of tax payments through price engineering that is transferred between divisions. The special relationship transaction between Taxpayers occurs if there is a condition that is suspected to influence the determination of the decision unreasonably. To anticipate state losses due to decreased tax revenues due to related transactions, the government has issued several regulations regarding the management of related transactions, such as the Minister of Finance Regulation (PMK No.213/PMK.03/2016). The Directorate General of Taxes (Direktorat Jenderal Pajak (DJP)) has the authority to re-determine the number of transfer prices between parties that have affiliated parties. This study uses a qualitative method using secondary data. Secondary data is in the form of other people's research, reviews, and summaries. In this study, the data taken is literature data that explains related to transaction tax management that is influenced by affiliated parties.
\end{abstract}

Keywords: Affiliated parties, transfer pricing, taxation

\section{Background}

The development of the world economy is happening rapidly as well as the economic development in Indonesia. This development has an impact on increasing international transactions or cross-border transactions. The company does not only limit its business activities in its own country but also expands its business activities to other countries and becomes a multinational company. In a multinational company environment, various transactions occur between members which include the sale of goods and services, licensing rights and other intangible assets, providing loans, and so on. These companies tend to form holding companies to coordinate their business. In the company's activities, usually, most of the business activities occur among themselves, namely in determining the price which is usually determined based on the transfer pricing policy determined by the holding company which will later be the same as the market price.

Problems in the field of taxation are often accompanied by the process of globalization and the rapid development of multinational companies, one of which is the determination of the fairness of transaction prices between domestic and foreign parties who have special affiliated parties. The term transfer pricing is very popular in determining transfer prices for transactions of goods, services, intangible assets, and financial transactions that are the company's activities. In this case, the government continues to encourage companies to conduct affiliate transactions at home and abroad. The Directorate General of Taxes obliges to prepare and submit transfer pricing documents following the reporting policies determined by both the members of the company and parties with specialties at home and abroad.

Transfer pricing carried out by holding companies tends to cause problems for the company, but it can also be an opportunity for companies that want to earn higher profits. The existence of transfer pricing transactions between companies usually occurs starting with affiliated parties between companies in obtaining income, which is an important indication for calculating taxable profit.

Transfer pricing is a sensitive issue in the business world and the global economy, especially in taxation. Transfer pricing activities carried out by multinational companies affect the level of state revenue in terms of taxes, either directly or indirectly. Transfer pricing is carried out by determining the amount of income earned by each company involved in the transaction and income tax receipts in the exporting country and the importing country.

There are several reasons and factors for companies, especially multinational companies, to transfer pricing. One of them is tax. The purpose of transfer pricing is to outsmart the company's profits so that the taxes paid and dividends distributed are lower. In this case, tax motivation has a high role in influencing the decision to transfer pricing.

Another factor that allows companies, especially multinational companies to make transfer pricing decisions, is tunneling. Tunneling is the transfer of resources from within the company to the controlling shareholder (Johnson, 2000: 22). The transfer of these resources can be done in various ways, one of which is through transfer pricing.

Another factor that can influence companies to transfer pricing is corporate governance. Good corporate governance cleanly runs the company, complies with applicable laws, and cares about the environment based on high sociocultural values. The elements of good corporate governance include shareholders, directors, board of commissioners, managers, employees, audit committees, investors, public accountants, audit quality, and so on (Sutedi, 2012: 12). 
Companies that have good governance will consider all their activities, especially for activities that deviate from the rules. This allows good corporate governance to influence companies in conducting transfer pricing.

This study will examine tax management in transactions that are influenced by special relationships. The special relationship which is the relationship between the Taxpayer and other parties as referred to in Article 18 paragraph (4) of the Income Tax Law or Article 2 paragraph (2) of the VAT Law will have an impact on the taxation aspects of each party having the special relationship. . It is the analysis of the tax impact of the related transaction that is the topic of the author's study. The title of this paper is: "Analysis of affiliated parties and transactions affected by affiliated parties".

\section{Theoretical Basis}

\section{Affiliated Parties}

According to PSAK No.7, a company can be said to have affiliated parties with another company if the company can control or have influence in making operational and financial decisions on other companies. Parties that have a special relationship are people or companies that still have a relationship (relationship) with the reporting company or the company that prepares the financial statements.

According to Law Number 36 of 2008 Article 18 paragraph, 4 affiliated parties can be formed if:

1) Presence of Equity Participation or Shares

Taxpayers have direct or indirect equity participation of at least $25 \%$ (twenty-five percent) to other Taxpayers; the relationship between Taxpayers and minimum participation of $25 \%$ (twenty-five percent) in two or more Taxpayers; or the relationship between two or more Taxpayers, the latter.

\section{2) Existence of Common Mastery (Management of} Technology)

Taxpayers exercise control over other Taxpayers or more Taxpayers under the same control, either directly or indirectly. Furthermore, based on the Elucidation of Article 18 of Law Number 36 of 2008, the control of management or the use of technology, even though there is no ownership relationship, is also indicated in the framework of affiliated parties. In addition, the existence of a related relationship is considered when there are one or more companies under the control of the same entity. This also applies between companies within the same control.

Government Regulation (PP) No.94 of 2010 concerning Calculation of Taxable Income and Settlement of Income Tax in the Current Year is one of the regulations that further regulates affiliated parties due to management control. In the regulation, it is explained that there are two affiliated parties due to management control, namely direct and indirect management control.

3) Family Relationships (Blood or Bloodline in Straight Lineage and/or Sideways One Degree)

There is a family relationship, either by blood or by marriage, in a straight line and/or one degree sideways. Furthermore, in his explanation, blood family relationships in a straight line of one degree are father, mother, and children. On the other hand, what is meant by blood family relations in the lineage to the side of one degree, namely siblings? In addition, marital families in a straight line of one degree are in-laws, and stepchildren and marital families in a straight line of one degree are in-laws.

\section{Affiliated Parties Transaction}

Based on the tax treatment of related transactions, related transactions are divided into two, namely as follows:

1) Tax Treatment on Domestic affiliated parties Transactions

Taxpayers who have domestic affiliated parties are:

- Affiliated parties (transfer pricing) between domestic individual taxpayers and domestic individual taxpayers.

- Affiliated parties (transfer pricing) between domestic individual taxpayers and domestic corporate taxpayers.

- Affiliated parties (transfer pricing) between domestic taxpayers and domestic taxpayers.

2) Tax Treatment on Foreign Relations Transactions

Taxpayers who have foreign-affiliated parties are:

- Affiliated parties (transfer pricing) domestic individual taxpayers with foreign individual taxpayers.

- Affiliated parties (transfer pricing) domestic individual taxpayers with foreign corporate taxpayers.

- Affiliated parties (transfer pricing) of domestic corporate taxpayers with foreign individual taxpayers.

- Affiliated parties (transfer pricing) of domestic corporate taxpayers with foreign corporate taxpayers.

\section{Transfer Pricing}

Transfer pricing is a company policy in determining the transfer price of a transaction, be it goods, services, intangible assets, or financial transactions carried out by the company. There are two groups of transactions in transfer pricing, namely intra-company and inter-company transfer pricing. Intra-company transfer pricing is transfer pricing between divisions within one company. Meanwhile, intercompany transfer pricing is transfer pricing between two companies that have affiliated parties. The transactions themselves can be carried out in one country (domestic transfer pricing) or different countries (international transfer pricing).

\section{Transfer Pricing in Indonesian Tax Regulations}

Regulations on transfer pricing are generally regulated in Article 18 of Law Number 36 of 2008 concerning Income Tax (UU PPh). Article 18 paragraph (3) of the Income Tax Law states that the Directorate General of Taxes has the authority to re-determine the amount of Taxable Income for Taxpayers who have affiliated parties with other Taxpayers following the reasonableness and practice of business that is not influenced by affiliated parties (arm's length principles). The authority of the Directorate General of Taxes is as follows:

1) Authority to Redefine Debt as Capital

The Director-General of Taxes is authorized to re-determine the amount of income and deductions as well as to determine debt as capital to calculate the amount of Taxable Income for Taxpayers who have affiliated parties with other 
Taxpayers following the fairness and normality of business that is not affected by affiliated parties by using the price comparison method. between independent parties, the resale price method, the cost-plus method, or other methods.

2) The authority to agree in determining the price of the transaction

The Director-General of Taxes is authorized to enter into agreements with Taxpayers and cooperate with other country's tax authorities to determine the transaction price between related parties, which is valid for a certain period, and supervises its implementation as well as renegotiating after the specified period ends.

\section{3) Authority to Determine the Real Party}

A taxpayer who purchases shares or assets of a company through another party or an entity formed for such a purpose (special purpose company), can be designated as the party that makes the purchase as long as the taxpayer concerned has affiliated parties with the other party or entity and there is a pricing irregularity. This provision is intended to prevent tax evasion by a Taxpayer who purchases shares/ investments in a domestic Taxpayer company through a foreign company that is specially established for that purpose (special purpose company).

\section{4) Authority to Assign Seller}

The sale or transfer of shares of an intermediate company (conduit company or special purpose company) established or domiciled in a tax haven country that has affiliated parties with an entity established or domiciled in Indonesia or a permanent establishment in Indonesia may be determined as the sale or transfer of shares of an entity established or domiciled in Indonesia or a permanent establishment in Indonesia.

\section{5) Authority to Redetermine the Amount of Income}

The amount of income earned by a domestic individual Taxpayer from an employer who has affiliated parties with another company that is not established and is not domiciled in Indonesia can be re-determined if the employer transfers all or part of the income of the domestic individual Taxpayer to in the form of fees or other expenses paid to the company which is not established and is not domiciled in Indonesia.

\section{Research Methodology}

The research methodology used is qualitative. Raco (2013) states that qualitative research is a theoretical idea with techniques and procedures to reveal facts in depth to obtain full information. The source of the data taken is secondary data which is data that is not obtained directly from the data source (Sugiyono, 2018). Secondary data is in the form of other people's research, reviews, and summaries. In this study, the data taken is literature data that explains related to transaction tax management that is influenced by affiliated parties.

\section{Discussion}

Definition of affiliated parties and transfer pricing. Affiliated parties is an ownership relationship between one company and another company and this relationship occurs because of a relationship, affinity, or dependence of one party with another party that is not found in a normal relationship, ownership or participation factors, control through management or use of technology, blood relationship or because marriage is a major factor in the emergence of affiliated parties. The existence of affiliated parties is the main factor causing the practice of transfer pricing. Factors causing affiliated parties will be important in determining the amount of income and/or expenses that will be charged for the calculation of taxable income.

Transfer pricing is defined as a special selling price used in inter-divisional exchanges to record the selling division's revenue and the buying division's costs. (Henry Simamora, 1999: 272). Transfer pricing is often also referred to as intracompany pricing, intercorporate pricing, interdivisional or internal pricing which is a price calculated for management control over the transfer of goods and services between members (groups of companies). Transfer pricing is usually set for intermediate products, which are goods and services supplied by the selling division to the buying division. If examined further, transfer pricing can deviate significantly from the agreed price. Transfer pricing is also often associated with a systematic price engineering aimed at reducing profits which will later reduce the amount of tax from a country.

\section{Purpose of transfer pricing}

The purpose of transfer pricing is to transmit financial data between departments or divisions of the company when they use each other's goods and services (Henry Simamora, 1999: 273) In addition to this purpose, transfer pricing is sometimes used to evaluate divisional performance. and motivates managers of the selling and buying divisions toward decisions that are in line with the overall company objectives.

Meanwhile, within the scope of multinational companies, transfer pricing is used to minimize taxes and duties that they incur around the world.

\section{Transfer pricing method}

Several transfer pricing methods are often used by a conglomerate and divisional/departmentalized companies, namely:

\section{1) Cost-Based Transfer Pricing}

Companies that use the transfer method on a cost basis set transfer prices for variable and fixed costs which can be in 3 forms, namely: full cost (full cost), full cost plus a mark-up (full cost plus mark-up), and a combination of variable costs. and fixed (variable cost plus fixed fee).

\section{2) Transfer Prices based on Market Prices (Market BasisTransfer Pricing)}

If there is a perfect market, the transfer pricing method based on market prices is the most adequate measure because of its independent nature. However, limited market information sometimes becomes an obstacle in using transfer pricing based on market prices.

\section{3) Negotiated Transfer Prices}

In the absence of a price, some companies allow the divisions within the company with an interest in transfer 
pricing to negotiate the desired transfer price. Negotiated transfer prices reflect the perspective of controllability inherent in responsibility centers because each of the divisions concerned will ultimately be responsible for the negotiated transfer prices.

Indonesian Tax Regulations on Transfer Pricing

The practice of transfer pricing can result in the transfer of income or the basis for imposition of taxes and or fees from one Taxpayer to another, which can be engineered to suppress the total amount of tax payable on a Taxpayer who has a special relationship.

Through the Director-General of Taxes Circular No. SE04/PJ.7/1993 Dated March 3, 1993, the Directorate General of Taxes stated that the irregularities of the existence of transfer pricing practices could occur due to:

1) Sales price

2) Purchase price

3) Allocation of general and administrative costs (overhead costs)

4) Interest charged on loans by shareholders (shareholder loan)

5) Payment of commissions, licenses, franchises, leases, royalties, fees for management services, fees for technical services, and fees for other services

6) Purchase of company assets by shareholders (owners) or parties who have a special relationship lower than the market price

7) Sales to foreign parties through third parties that lack or have no business substance (eg dummy company, letterbox company, or reinvoicing center).

To prevent tax evasion, among others through the determination of an unreasonable price (non-arm's length price), in the tax laws some provisions give the tax authorities the authority to make corrections to unfair transactions with third parties. others who are related.

Article 18 paragraphs (1), (2), and (3) of Law no.36 of 2008 concerning Income Tax stipulates that:

1) The Minister of Finance is authorized to issue a decision regarding the ratio between debt and company capital to calculate taxes based on this law.

2) The Minister of Finance has the authority to determine the time when dividends are earned by a resident Taxpayer on capital participation in a foreign business entity other than a business entity that sells its shares on the stock exchange, with the following provisions:

a) the amount of capital participation of the said resident Taxpayer is at least $50 \%$ (fifty percent) of the total paid-up shares or

b) Together with other domestic Taxpayers have equity participation of $50 \%$ (fifty percent) or more of the total paid-up shares.

3) The Director-General of Taxes has the authority to redetermine the amount of income and deductions as well as to determine debt as capital to calculate the amount of Taxable Income for Taxpayers who have affiliated parties with other Taxpayers following the fairness and normality of business that is not influenced by affiliated parties by using the comparison method. pricing between independent parties, the resale price method, the costplus method, or other methods.
The Decree of the Director-General of Taxes Number: KEP01/PJ.7/1993 concerning Guidelines for Tax Audits of Taxpayers with affiliated parties is also intended to overcome the decline in the amount of tax paid through transfer pricing practices. This Decree regulates the stages of inspection that need to be carried out by the competent authority to the transfer pricing practice, namely:

1) Studying Taxpayer files and data files. This stage is done by studying the notarial deed and its amendments. It must be examined whether from the structure of the ownership of the shares of the Taxpayer being audited it appears that there are affiliated parties as referred to in Article 18 paragraph (4) of the Income Tax Law no.10 of 1994 and Law no.11 concerning Value Added Tax Article 2 paragraph (1). Theobjectives to be achieved are to find out the general description of taxpayers, which include:

- Regarding the business and characteristics of the company

- Regarding the structure of share ownership, is there a possibility of affiliated parties between the shareholders and the Taxpayer being audited?

- Studying the organizational structure of related companies. As far as possible, it is attempted to describe the organizational chart of companies that have special and economic relationships with the audited taxpayers that provide an overview and location of activities.

- Study the nature and types of business activities of the Taxpayer. As far as possible, the business activities of the Taxpayer are described from the time the order is placed to the completion of the order, both regarding purchases and sales.

- Studying the possibility of over/under invoicing. Purchases/imports and sales/exports made by taxpayers who have affiliated parties with suppliers and customers who are mainly domiciled in Tax Heaven Countries, the possibility of over and under invoicing must be studied.

- Studying previous inspection reports. This aims to find out the things referred to in letters b, c, and $d$ above so that they can be used as instructions in the examination to be carried out.

2) Analyzing the SPT and Financial Statements of the Taxpayer The purpose of this analysis is to detect irregularities in the sale or purchase price between the parties who have affiliated parties. To do this, a generally accepted ratio analysis is used.

Chapter III of the Decree of the Director General of Taxes Number: KEP 01/PJ.7/1993 also regulates the audit methods used in determining the market price (market price or arm's length price) in affiliated parties These methods are as follows:

3) The comparable market price method. This method can be used in case of:

- There are sales/purchases to parties who have a special relationship, or to parties who do not have an affiliated party. 
- The type of product as the object of the transaction is relatively the same.

The things that must be considered when using this method are:

- Geographically distinct markets

- Sales chain from producer to consumer

- Discounts and quantity discounts (discounts and rebates)

- Quality of goods

- Insurance

4) Minus Selling Price Method. This method can be used in the case of:

- There are no transactions with unrelated parties that can be used as a comparison, for example in a single agency marketing system

- There is data on the resale price of goods that are not affected by affiliated parties

- There is no process of changing goods that add value

- The buyer and seller in affiliated parties do not increase the price which has a large effect on the value of the goods

5) Cost of Goods Plus Method.

The things that need to be considered in using this method are:

- Allocation of costs to the cost of goods

- Determination of the direct costing method in determining the selling price

- Use of technology that can save raw materials and working hours

- Request price from the customer.

Anticipating Tax Risk in Affiliated Parties Transactions Compliance with fulfilling tax obligations is measured and compared with the size of tax savings, tax avoidance, and tax evasion, all of which aim to minimize the tax burden. Tax evasion that is carried out illegally is tax evasion or it can also be considered tax evasion, namely doing tax evasion which is not allowed in the tax laws and regulations. Companies that have good governance will consider all their activities, especially for activities that deviate from the rules. This can enable good corporate governance to influence companies in conducting transfer pricing.

Types of affiliated parties transactions that have high tax risk following Article 18 paragraph 3 of the Income Tax Law include the following:

1) For business transactions, according to Article 18 paragraph (3) of the Income Tax Law, the Directorate General of Taxes is authorized to re-determine the amount of income and expenses to calculate the amount of taxable income for taxpayers who have affiliated parties with other taxpayers following fairness and the prevalence of business that is not influenced by affiliated parties.

2) For loans, according to Article 18 paragraph (1) of the Income Tax Law, the Minister of Finance is authorized to determine a reasonable interest rate on debt and receivable transactions between related parties. this will cause the company to lose because it has to withhold
Article 23 Income Tax based on a reasonable interest rate and there is a possibility of being penalized by the tax office for lack of tax deductions. For the parent company, the interest income will be corrected positively so that the taxable profit will be higher.

3) Receivable transactions in the form of reimbursement costs which are usually carried out between parent and subsidiary funds have the possibility of tax implications in the form of an obligation to collect VAT and or withhold Income Tax Article 23. This can occur if the tax office indicates that there is an object of VAT collection and an object of tax withholding. income on accounts payable transactions from the related relationship.

So that the risks described above can be anticipated to a minimum, companies need to do the following:

1) Efforts are made as much as possible so that transactions for purchasing goods or using services, which are usually carried out by the parent company, can be carried out directly by the company that uses them. Thus, there is no affiliated parties payable transaction between the subsidiary and the parent company. This method can minimize the risk of collecting VAT and withholding Income Tax Article 23 due to related debt transactions.

2) If interest-free loans are granted to subsidiaries, the criteria as stated in Article 12 of Government Regulation no.94 of 2010 which took effect on December 30, 2010, are as follows:

a) The loan comes from funds belonging to the lender's shareholders and not from other parties.

b) The capital that should have been paid up by the lender's shareholder to the company receiving the loan has been fully paid up.

c) The lender's shareholders are not at a loss.

d) The company receiving the loan is experiencing financial difficulties to continue its business.

If one of the four elements above is not met, the loan will be corrected by the tax office and become payable with interest at a fair interest rate. This will increase the cost burden for the company. Therefore, if there is a lending and borrowing transaction between the company and the parent company, it is necessary to make a loan agreement that at least contains the principal, the term, and the interest rate charged. If no interest is charged, this must be expressly stated in the agreement.

1) Prepare Transfer Pricing Documentation or documentation of transfer prices according to the Director-General of Taxes Regulation (Director General of Taxes Regulation No. Per-32/PJ/2011).

Article 2 PerDirjen Tax No. Per-32/PJ/2011 stipulates that the scope of Transfer Pricing Documentation is:

1) Transactions on transactions made by Domestic Taxpayers or Permanent Establishments in Indonesia with Foreign Taxpayers outside Indonesia;

2) Transactions carried out by Domestic Taxpayers or Permanent Establishments in Indonesia with parties that have affiliated parties to take advantage of the difference in rates due to, among others:

a) Treat the imposition of final or non-final Income Tax on certain business sectors; 
b) Treatment of the imposition of Sales Tax on Luxury Goods; or

c) Transactions conducted with Taxpayers of Oil and Gas Cooperation Contract Contractors;

Article 3 Per-32/PJ/2011 stipulates that the Taxpayer in conducting transactions with parties having affiliated parties is required to apply the Principles of Fairness and Business Ordinance. The basic principle is the norm that the price or profit on transactions carried out by parties who do not have a relationship is determined by market forces so that the transaction reflects a fair market price (Fair Value Market/FMV).

The Principles of Fairness and Business Ordinance are carried out with the following steps:

a) Perform comparability analysis and determine comparisons;

b) Determine the appropriate Transfer Pricing method;

c) Applying the Principles of Fairness and Business Ordinance based on the results of the comparative analysis and the appropriate method of determining the transfer price into transactions between Taxpayers and related parties; and

d) Documenting every step in determining a fair price or fair profit following the provisions of the applicable tax laws.

A Taxpayer is not obliged to apply the principle of fairness and normality of business if the Taxpayer conducts a transaction with related parties with the total transaction value not exceeding Rp.10, 000, 000, 000.00 in 1 (one) tax year for each counterparty. In conducting a comparability analysis, the following must be considered:

a) Transactions carried out between Taxpayers and related parties are considered comparable to transactions between non-related parties in terms of:

- There are no material or significant differences in conditions that can affect the price or profit of the compared transactions; or

- There is a difference in conditions, but adjustments can be made to eliminate the material or significant effect of the difference in conditions on prices or profits;

b) If internal comparative data and external comparative data are available with the same level of comparability, the Taxpayer is obliged to use internal comparative data for determining fair prices or reasonable profits.

\section{Conclusion}

The existence of affiliated parties is the key to the practice of transfer pricing in the taxation sector. The practice of transfer pricing is often used by many companies as a tool to minimize the amount of tax that must be paid to the state. The affiliated parties in taxation are characterized by the existence of a relationship between two or more Taxpayers who are under the same ownership or control either directly or indirectly, there is a relationship between Taxpayers who have $25 \%$ or more participation in the other party. Affiliated parties are also characterized by the existence of family ties both by blood and by marriage in a straight line and/or one degree aside.
Abnormalities of the transfer price (non-arm's length price) caused by the practice of transfer pricing can occur on: the sale price; purchase price; allocation of administrative and general costs (overhead costs); charging interest on lending by shareholders (shareholder loan); payment of commissions, licenses, franchises, leases, royalties, fees for management services, fees for technical services and fees for other services; purchase of company assets by shareholders (owners) or parties who have affiliated parties lower than the market price.

This transfer pricing problem is overcome by giving the authority to the minister of finance and the director-general of taxes to re-determine the amount of income and deductions as well as to determine debt as capital to determine the amount of Taxable Income for parties who have affiliated parties. In addition, to check the existence of transfer pricing practices, the Directorate General of Taxes issues Tax Audit Guidelines for Taxpayers with affiliated parties.

Companies that have good governance will consider all their activities, especially for activities that deviate from the rules. This can enable good corporate governance to influence companies in conducting transfer pricing.

So that tax risks related to related transactions can be anticipated to a minimum, companies need to do the following:

1) Efforts are made as much as possible so that transactions for purchasing goods or using services, which are usually carried out by the parent company, can be carried out directly by the company that uses them. Thus, there is no special relationship payable transaction between the subsidiary and the parent company. This method can minimize the risk of collecting VAT and withholding Income Tax Article 23 due to related debt transactions.

2) If interest-free loans are granted to subsidiaries, the criteria as stated in Article 12 of Government Regulation no.94 of 2010 which took effect on December 30, 2010, are as follows:

a) The loan comes from funds belonging to the lender's shareholders and not from other parties.

b) The capital that should have been paid up by the lender's shareholder to the company receiving the loan has been fully paid up.

c) The lender's shareholders are not at a loss.

d) The company receiving the loan is experiencing financial difficulties for its business continuity.

If one of the four elements above is not met, the loan will be corrected by the tax office and become payable with interest at a fair interest rate. This will increase the cost burden for the company. Therefore, if there is a lending and borrowing transaction between the company and the parent company, it is necessary to make a loan agreement that at least contains the principal, the term, and the interest rate charged. If no interest is charged, this must be expressly stated in the agreement. 


\section{References}

[1] Prianto Budi S., (2016). Manajemen Pajak Edisi 2. Jakarta: PT Pratama Indomitra Konsultan.

[2] Raco, (2010). Metode Penelitian Kualitatif: Jenis, Karakteristik, dan Keunggulannya. Jakarta: PT Grasindo.

[3] Sugiyono, P., (2018). Metodologi Penelitian Mix Method. Bandung: Alpabeta.

[4] Dwi Noviastika F, Yuniadi Mayoman dan Suhartini Karjo, (2016). Pengaruh Pajak, Tunneling Incentive dan Good Corporate Governance (GCG) terhadap indikasi melakukan Transfer Pricing pada perusahaan manufaktur yang terdaftar di Bursa Efek Indonesia (Studi pada Bursa Efek Indonesia yang berkaitan dengan perusahaan asing) Jurnal Perpajakan (JEJAK) Vol.8 No.1.

[5] Sutedi, Adrian, (2012). Good Corporate Governance. Jakarta: Sinar Grafika.

[6] Johnson, S., La Porta, R., Lopez-de-Silanes, F., Shleifer., A., (2000). Tunneling The American Economic Review.90 (2), 22-27.

[7] Yenni Mangonting, (2000). Aspek Perpajakan Dalam Praktek Transfer Pricing Jurnal Akuntansi dan Keuangan Vol.2 No.1.

[8] Amor Marundha, Achmad Fauzi dan Rachmat Pramukty. Pengaruh Hubungan Istimewa Perusahaan terhadap Penghindaran Pajak yang Di mediasi oleh Tax Heaven Country. Jakarta: Universitas Bhayangkara.

[9] Annisa Fitri Ratnasari, (2021). Perlakuan Pajak Atas Transaksi Hubungan Istimewa: Media Pajak Starup.

[10] Reyhan Audric, (2019). Pengaruh Hubungan Istimewa Dalam PPh Badan: Media Pusat Pelatihan Perpajakan Koperasi Pegawai Pajak.

[11] Peraturan Pemerintah Nomor 94 Tahun 2010 tentang Perhitungan Penghasilan Kena Pajak dan Pelunasan Pajak Penghasilan Dalam Tahun Berjalan.

[12] PeraturanMenteriKeuanganNomor 213/PMK.03/2016tentangJenis dokumen dan/atau informasi tambahan yang wajib disimpan oleh wajib pajak yang melakukan transaksi dengan para pihak yang mempunyai hubungan istimewa dan tata cara pengelolaannya.

[13] PSAK No.7 tentang Pengungkapan Pihak-Pihak Berelasi.

[14] Undang-Undang Nomor 36 Tahun 2008 tentang perubahan ke empat atas Undang-Undang Nomor 7 Tahun 1983 tentang Pajak penghasilan.

[15] Surat Edaran Dirjen Pajak No. SE-04/PJ.7/1993 tanggal 3 Maret 1993.

[16] Keputusan Direktur Jenderal Pajak No. Kep01/PJ.7/1993 tentang Pedoman Pemeriksaan Pajak terhadap wajib pajak yang mempunyai hubungan istimewa.

[17] Peraturan Dirjen Pajak No. Per 32/PJ/2011 perubahan atas per-43/PJ/2010 tentang penerapan prinsip kewajaran dan kelaziman usaha dalam transaksi antara wajib pajak dengan pihak yang mempunyai hubungan istimewa. 